Revista Iberoamericana, Vol. LXX, Núm. 206, Enero-Marzo 2004, 125-140

\title{
IDENTIDAD Y ALTERIDAD \\ ESCRITURA FEMENINA EN EL CICLO DEL POSGOLPE CHILENO: MALDITA \\ YO ENTRE TODAS LAS MUJERES DE MERCEDES VALDIVIESO Y DOY POR VIVIDO TODO LO SOÑADO DE ISIDORA AGUIRRE
}

\author{
POR \\ Silvia CRISTINA Rodríguez \\ Universidad Nacional de Cuyo
}

Mire hay una frase muy linda del poeta inglés John Keats, que dijo que hacer crítica literaria era como unweave the rainbow, de destejer el arco iris. Es decir, el arco iris es algo que podemos llamar milagroso, que no puede destejerse evidentemente. Jorge Luis Borges

LA SOCIEDAD CHILENA Y LA FICCIÓN LITERARIA

El tema de la sociedad chilena es una constante de las generaciones narrativas de la primera mitad del siglo xx. Esta singular relación de la literatura con la historia nos permite hacer nuestra la afirmación de que Chile es, en esa etapa, un país de historiadores, con predominio de la novela autobiográfica. Línea diacrónica que desde una perspectiva finisecular se proyecta desde la Poética de 1920. Como otra manera de definirse por oposición o por identidad con la tradición, Ángel Rama ha caracterizado a esta literatura cuyo eje temático es la descomposición de clase como "realismo de la decrepitud".

El debate historiográfico amplía el abordaje literario de los hechos sociales proyectando las posibles interpretaciones de los referidos a la consolidación de la tradición cultural, en un plano narrativo más particular: el orden privado del espacio doméstico familiar. Temática que estructuralmente responde a formas canónicas que evidencian la pertenencia a una cultura determinada, a un modo de percibir la realidad y a un modo estatutario de orden privado, que regula relaciones de pertenencia y raigambre social, con textos que particularizan las modalidades del país de origen.

Orden éste que podrá leerse diacrónicamente en la década del sesenta al setenta, en rupturas históricas (externas), con quiebres institucionales, pérdida de la paz social, así como desde un orden familiar subvertido por el reacomodamiento de la desbordada estirpe familiar. Proceso que en indirecta o directa conexión con situaciones de inestabilidad político-social intenta una búsqueda, consciente o no, esforzada o indolente por adquirir mayor conciencia personal y social.

América Latina a través de su literatura demuestra la capacidad de traspasar la apariencia de realidad normal y desnudar los conflictos de su verdadera existencia enmascarada; ya sea por el poder omnímodo o por el postulado de subordinación del discurso masculino. Esta es la hipótesis general que estructura el presente trabajo, cuyo 
objeto es el estudio de dos escritoras insertas en el Ciclo denominado del Posgolpe chileno: Mercedes Valdivieso e Isidora Aguirre.

La filiación teórica puede ubicarse en los estudios de Paul Ricoeur, basados en evaluaciones histórico-sociológicas, que alcanzaran un relevante sentido dinámico de realidad presente tanto en la Filosofía de la Imaginación como en todo su proyecto filosófico general. Sus presupuestos básicos son la ideología y la utopía, que tipifican la imaginación social y cultural.

La posibilidad innegable del discurso literario latinoamericano se ubica, hoy, en la desacralización y lo que Ricoeur concibe como utopía, en esta instancia de análisis, posee la fuerza de re-describir la vida (Ricoeur). Así, la imaginación social al preservar un orden, se vuelve reproductiva, y está en la ideología, mientras que, si es productiva destruye y cuestiona el orden de la realidad, y se vuelve imaginación entendida como ficción. Porque, la utopía pone en tela de juicio lo que existe actualmente, emerge como la exploración de lo posible. No es un sueño: es un proyecto a realizarse.

Dos MUJERES EN LA LITERATURA DEL POSGOLPE CHILENO

Mercedes Valdivieso e Isidora Aguirre, como escritoras insertas en el corpus de la literatura del Posgolpe chileno, son voces que desde el espacio personal-familiar, en el que guardan permanente contacto con sus antepasados, formulan una escritura intersticial contra-hegemónica, al mismo tiempo que construyen un sistema de significación textual que nos permite reconstruir la memoria del pasado.

El significante mujer, presencia material del signo, es la utopía que nos revela la conciencia de legitimación de la condición social y personal de la mujer frente a factores culturales y económicos que se muestran como altamente discriminatorios. Esta doble perspectiva de dominación se abre como diáspora al considerar como hipótesis particulares las distopías de ambas obras en su especificidad de discurso ficcional, donde importa la presencia lingüística de la ideología, en las marcas textuales que prueban su inscripción. Ricoeur analiza dos niveles,

1-La ideología como fuerza integradora social que legitima la autoridad.

2-La utopía como lo otro, como lo posible, desafía la autoridad (afronta el problema del poder mismo). (Ricoeur, Conferencia I, 32)

Como en todas las formas de legitimación y en los sistemas de autoridad existe una disparidad de credibilidad. La utopía trabaja para exponer esa brecha, entre las pretensiones de autoridad y las creencias de la ciudadanía en cualquier sistema de legitimidad ya que las ideologías como paradigmas están sujetas a la crítica de las utopías. Esta hermenéutica como teoría de la interpretación confirma que debemos mantener esa dialéctica en el momento crítico de la interpretación: debemos poder confrontar lo que podemos ser, como proyecto utópico, con lo que podemos ser (Ricoeur, Conferencia I, 33).

De esta forma, la conjunción entre ideología y utopía es constitutiva de nuestra vida social y, en consecuencia, al armonizar el núcleo mito-poético de la imaginación se afronta el desafío de una hermenéutica de la sospecha. El conflicto de las interpretaciones es un 
juego de similitudes y diferencias que, en la interrelación de su práctica, nos induce a “pensar más”. Es justamente a partir de que los sistemas simbólicos ayudan a interpretar los conflictos y hacen a la comprensión de las culturas que se articula la coincidencia entre la teoría de Paul Ricoeur y el pensamiento de Clifford Geertz, desarrollado en el ensayo "La interpretación de las culturas". ${ }^{1}$

LA NARRATIVA DEL POSGOLPE CHILENO, LA DÉCADA DEL OCHENTA

La presencia de producción y circulación de textos ficcionales en veinte años de historia latinoamericana dan cuenta de lo sucedido en algunos países del continente bajo las experiencias de gobiernos de dictaduras militares. La relación entre discurso histórico y discurso ficcional se encuentra, sustentada materialmente en dos vertientes: producción cultural y comunicación social, que manifiestan esa circulación textual desde dos locus de enunciación particularmente diferenciados: producción interna y escritura de exilio, como dos cánones de una unidad binaria. La literatura y la cultura chilenas del Golpe y el Posgolpe funcionan dentro de un sistema nacional que conecta ambas instancias. Por otra parte, es necesario dejar sentado que la bibliografía de la obra producida en el exilio es incompleta, pues su circulación, en algunos casos fue posible -caso Isabel Allende, Jorge Edwards, José Donoso-, y en otros, la referida circulación ha sido más tardía.

La narrativa de este ciclo es un fenómeno multigeneracional; como descripción de las generaciones elaboradas más formalmente podemos encontrar a la Generación Neorrealista del 42, que incluye los nacidos entre 1905 y 1919: Fernando Alegría y Volodia Teitelboim. Asímismo, a la Generación Irrealista del 57, cuyos integrantes nacieran entre los años 1920 y 1934: José Donoso, Jorge Edwards y Hernán Valdez. De los nacidos entre 1935 a 1945, se encuentran los Nuevos o Novísimos Narradores del setenta, así como una generación de relevo, posterior, conocida como la de Emergencia Literaria. Finalmente, entre los escritores establecidos fuera de Chile, se produce una corriente generacional entre los más jóvenes que recién empezaban a publicar, o nunca llegaron a hacerlo dentro de Chile (Zurita).

La década del ochenta representa un momento de cambio que marca a la literatura, en general, y a la producción narrativa, en particular, como un momento de transición. El golpe militar de 1973, vivido como un quiebre institucional y cultural produjo la aparición, en el interior de Chile, de discursos literarios autorreferentes, que tematizan entornos circunscriptos a limitadas esferas personales. En este sentido, Raúl Zurita detecta un cambio en la segunda etapa de la dictadura que retrospectivamente sería percibido como una superación del proyecto de ruptura con el desarrollo político, social y cultural de los cuarenta años anteriores al régimen militar, la cultura del pasado. Se evidencia la superación de percepciones físicas y la intención de interrelacionar las experiencias personales con las colectivas, por parte de los autores. La literatura se adelanta así, en

\footnotetext{
${ }^{1}$ Coincidencia del pensamiento de Clifford Geertz con la teoría de Paul Ricoeur sobre este tópico puede ser hallado en el ensayo de este autor: "La interpretación de las culturas" en, La ideología como sistema cultural.
} 
cierto modo, a los discursos que, al poner el énfasís en la reunificación, comienzan a ganar unanimidad en la sociedad chilena (Zurita 20-21).

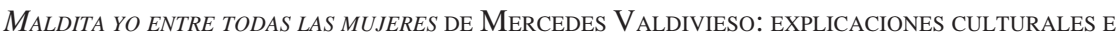
históRicAs. El Mito dE LA Quintrala

La transposición del Mito de la Quintrala, en esta novela de Mercedes Valdivieso nos remite a dos particularidades que registra, en general, la literatura del post-boom: el reingreso de la historia en la ficción, y un pacto de lectura donde el lector toma la coreferencialidad interna de la obra como verídica. Así, este lector aparecerá superando, a través de una lectura fáctica, el principio de verosimilitud, como una construida ilusión de realidad, cliché de los mass media de la década del setenta al ochenta, instancia que compromete en su interpretación el grado de competencia del lector.

Esta novela actualiza el discurso social configurado por el estado de ficción de derecho -Leyes de Indias- y la situación de hecho en las colonias españolas del Reino de Chile, a mediados de 1600, que encubre la violación cultural bajo la mal llamada “extirpación de idolatrías”. Conflicto éste cuya relación inseparable entre pensamiento mítico e historia está actualizada en la difusión popular del mito de La Quintrala, núcleo central de la novela.

La dimensión macrosocial históricamente aceptada denota un sistema instituido de dependencias y obediencias desde la cultura blanca patriarcal, el arrasamiento de las etnias aborígenes, la implantación de las culturas europeas, y una retórica eclesiástica que justificaba el dominio. En síntesis, desde una perspectiva global, el postulado de la obediencia funcionaba socialmente como garantía de supervivencia y síntesis ideológica.

Mito, SUJETO HISTÓRICO Y DISCURSO SOCIAL

Es imposible no ocuparnos tanto de la presencia del mito como de hacer referencia a un momento preciso de la historia, ambas como partes constitutivas del funcionamiento simbólico que registra el texto. La comprensión es más profunda a partir del enfoque interno de esa cultura o sociedad que lo produce ya que la necesidad de rehacer antiguos vínculos sociales y sagrados como vías de recuperación y conocimiento del pasado actualizan el mito en la capacidad de migración y mutación ideologemática de su retransmisión discursiva.

La actualización del mito en el discurso social se concreta bajo presupuestos de aceptabilidad que mediatizan tanto la imagen como la palabra. La filmografía por ejemplo recupera a su favor la dramatización visual y acústica. Tal es el caso del mito de la Quintrala, cuya difusión televisiva bajo las formas de telenovela y teleteatro en los países del área andina, ha influido cuantitativamente sobre las expectativas del conocimiento de una leyenda popular a través de su mímesis histórica. Allí el símbolo es mucho más que su expresión lingüística, la comunicación está hecha de signos verbales y no verbales y podemos precisar lo que es conocido como la desmitologización del mito (Pierrele Bertand Roussel). 
En este vasto intercambio simbólico a través de la palabra, la lengua es conservadora y transmisora de la cultura. El sustento ideológico de la mitología andina está formado por la tradición precolombina y por la tradición teológica española, trasfondo que corresponde a la invención de la palabra mítica andina (Henrique Urbano). No hay que olvidar que severas medidas represivas se extendieron por varias décadas, y desde una lectura llevada adelante por la crónica de los siglos XVI y xvir hecho éste que no puede dar lugar a una referencia ingenua en lo que respecta a la invención de la mitología andina. Así, el pensamiento mítico hispánico cae presa de la apropiación y consecuente imposición simbólica a partir de lo cual, el pensamiento pre-hispánico pasa a significar al invasor. ${ }^{2} \mathrm{El}$ choque entre las dos culturas, la prehispánica y la cristiana tenderá, entonces, a someter a la primera, historizando el mito, al manipularlo en un contexto de poder socio-político y religioso: Wiracocha transformado en Dios único y verdadero del evangelizador español (Urbano 28).

Desmitologizar el mito es poder encontrar en su relato la coexistencia de campos discursivos que delaten qué elementos o segmentos se introducen él y cuáles son los rasgos novedosos que patentizan una interferencia ideológica. La inscripción textual permite ver cómo circulan esos ideologemas - unidades significativas mínimas-y cómo se transforman mediante reglas de coerción y estrategias implícitas en todo tipo de discurso. Es lo que Paul Ricoeur llamaba la dimensión semántica, lo que constituye la estructura profunda de la interpretación.

Así, recomponer el campo semántico de un mito, tanto lo que se enuncia cuanto el contexto en que se produce y reproduce no es tarea fácil, porque en el campo de la filosofía simbólica todo producto simbólico significa aunque no lo hace de cualquier manera. El trabajo de exégesis de la significación posee diferentes niveles según el criterio aplicado; un criterio puede ser el que toma el mito para trabajar la intertextualidad en el marco interdiscursivo. En la particularidad de una cultura originaria existen conjuntos de relatos o ciclos que funcionan de acuerdo a lo que Lévi Strauss propusiera como finalidad del mito: describir una situación encarnada o dramatizada en gestos o palabras por héroes o protagonistas, a través de la cual se proyectan las tensiones sociales o percepciones acerca del mundo y de las cosas para las cuales las sociedades buscan una explicación.

Asimismo, son las contradicciones planteadas por las reglas de parentesco o matrimonio y, también, las observaciones de carácter cosmológico o cosmogónico los casos más frecuentemente estudiados por este autor. En este marco, esta interpretación sería la que mejor explique la relación inseparable entre pensamiento mítico e historia en la novela trabajada cuyo personaje central es la mestiza Catalina de los Ríos y Lisperguer, conocida a través de la leyenda popular como La Quintrala (apodo que refiere al quintral, del araucano caulth, planta, espino que mata al árbol que la sostiene).

\footnotetext{
${ }^{2}$ Para ampliar este tema consultar los estudios publicados en Gabriela Ramos y Enrique Urbano, compiladores. Catolicismo y extirpación de idolatrías S. XVI- XVII, Charcas, Mejico, Chile, Peru. Cuadernos para la Historia de la Evangelizacion en America Latina.
} 


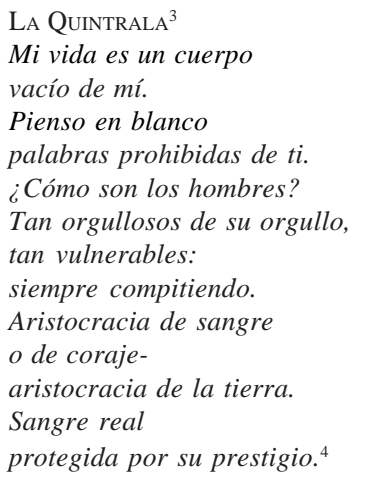

Presentar LA Historia, MESTIZAJE y FRONTERA

En esta novela de marcado perfil histórico-mítico el cronotopos narrativo se ubica en el Reino de Chile, en dependencia directa del Virreinato del Perú, a principios del año 1600 , donde la preocupación fundamental del colonizador era poblar nuevas tierras. El abandono de las ciudades fundadas al sur del río Bío-Bío por parte de los españoles como consecuencia del levantamiento general de los domésticos ${ }^{5}$ al sur de Chile, proporcionó un rico botín a los mapuches. De los cientos de prisioneros tomados muchos fueron mujeres y niños, comenzando así un proceso de mestizaje al invertido (1598-1657).

Biológicamente se inicia un proceso de homogeneización física, que se expande tanto por el centro como por el interior de las fronteras del reino. Culturalmente se trata de desplazamientos de indígenas o españoles que conservan los modos de vida respectivos. En nuestra concepción la homogeneidad biológica no va acompañada de su equivalente expresión cultural.

Desde 1657, la estabilidad del sistema fronterizo había permitido que los españoles que se asentaran en territorio mapuche se indigenizaran, por lo que ellos y sus hijos, como cautivos, se identificaron con los linajes territoriales, donde hicieron valer sus derechos a tierras o a la sucesión del cacicazgo. En cambio en las zonas dominadas por los españoles debieron integrarse al grupo de ellos, dentro de la jerarquía social de la Colonia.

Cuando se ingresa en la problemática del mestizaje colonial es imposible dejar de señalar que, a lo largo de tres siglos, adoptó motivaciones diferentes, y que el mestizo culturalmente no existió: hijo de grupos étnicos distintos, tendió a identificarse con la sociedad de uno de ellos, su realidad biológica no le impidió decidir por sí mismo.

\footnotetext{
${ }^{3}$ Catalina de los Ríos y Lisperguer, personaje histórico en el Virreinato del Perú, siglos XVI y XVII. Mestiza, que mantuvo concubinato con los de su propia sangre: su primo de la Orden de los Dominicos, y su medio hermano el bastardo Lisperguer.

4 Véase Silvia C. Rodríguez, La Alteridad, poemario en Trampas y fuego, con otros, inédito.

${ }^{5}$ Indios esclavizados destinados a las tares de servicio doméstico.
} 
Significar la historia, lo que Michel Foucault propone como permitir que la verdad ficcione. En este sentido, la historia documentada avala, en esta zona de préstamo entre lo factual y la ficción, un estado de rebelión latente y surgente, vencer o ser vencidos, contrapuesto a la estructurada dominación colonial. Para lo cual es válido recordar que la Corona española fue instrumento de represión y explotación de los conquistados; no un estado mediador por medio de una legislación humanitaria, y que la clase dominante en las colonias, era la misma clase dominante en España, la clase de los feudales españoles. Fenómeno de ficción legal o de hipocresía jurídica, que en nuestras latitudes adoptó desproporcionadas dimensiones. Ciudad indiana, la de la novela, particulariza este estado de rebeldía latente que el texto caracteriza: La ciudad que está en relación de ser capital del nuevo y último extremo del mundo, de la que da cuenta Alonso de Ribera, gobernador al virrey Don Luis de Velazco, en la misiva “de su puño y letra” que nos introduce en la realidad de la ficción. Escenario de la historia de Catalina de los Ríos, descendiente por vía materna de la cacica de Talagante, e hija de Don Gonzalo de los Ríos.

LA CONDICIÓN MUJER

Desde el estatuto de lo neutro que pretende identificar lo humano con lo masculino, la condición mujer ha sido depurada históricamente en un marginal espacio de indefensión e indefinición. El titulo de la obra, Maldita yo entre todas las mujeres, invierte en la transcripción literaria el “Bendita tú entre todas las mujeres” perteneciente al Ave María. Inscripción textual que prefigura una original y premeditada condena a la condición mujer de la Quintrala, al mismo tiempo que se instala como alusión significativa a un estigma de maldición, causado por los pleitos y procesos legales que se le siguieron, en razón de los cargos de asesinato de su progenitor -quien muriera envenenado en su propia casa- y el de intento de envenenamiento al gobernador, Alonso de Ribera: "arrepentirme de atenderla me llevo a toparme con la muerte”.

También víctima en el fallido duelo de Juan Pacheco: “casi hermano, casi fraile, casi encomendero" (Valdivieso 12-13).

Pues deberá optar entre los hábitos religiosos y los negocios de la guerra, amor sacrílego de doña Catalina, por deberse éste al amor de Dios, y por ser parte del concubinaje de su propia sangre, como también lo fuera Segundo Antivil: "bastardo de su padre y antojo de su cama”.

Segundo a secas supo elegir su sitio: mejor bastardo que legítimo a medias, como los mestizos que regresaban a la mitad de su sangre. Tradición de conspiraciones, envenenamientos, y sentencias favorables. Poder de los linajes heredados, o convenidos por la vía del parentesco con funcionarios, suficientemente poderosos como para lograr fallos favorables con funcionarios, ante la Real Audiencia de Lima. Fallos que no lavaron la sangre de Segundo, quien muere en una emboscada por haberse pasado a los mapuches, y paga a Enríquez, con su vida, el desdén de su media hermana.

Porque, la Quintrala es irreverente con Dios, con la Ley y con su propio padre; no hay quién pueda sujetarla, el confinamiento no le sienta a un espíritu libre: "hay que encerrarla en el cuerpo. Las endemoniadas y las brujas son antecesoras histéricas del orden subvertido, así las nombra el Manual de los Inquisidores. La virginidad del harén, el 
convento son lugares comunes de reclusión de la mujer en su cuerpo” (Rodríguez, Rosa María 69-71).

El convento de las Clarisas será, entonces, el destino transitorio que dispondrá la Iglesia para evitar al mundo de tan peligroso contacto. Se teme a quien se oprime, y se le asigna una esencia maléfica para justificarse. Pero el confinamiento ideológico es una convención implícita, saber callar es un conflicto entre lo autorizado y lo prohibido, amoldarse a los cánones de la escolástica, constreñida vida de censuras y permisos que fueron parte de la rutina virreinal. Desde una perspectiva unipersonal, en un plano formal de confesión: del total de diez capítulos, siete asumen el Yo de la voz que narra.

El silencio de la mujer responde a un modelo impuesto y socialmente controlado por un neutro testigo colectivo, los tres restantes, intercalados en la estructura general responden a una tercera persona del plural: Dicen que..., el relato cambia el punto de vista y se focaliza en el espacio público. Este ordenamiento aséptico reproduce el incontaminado estamento jerárquico que uniformemente pretendía implantar España en la sociedad colonial.

En este marco, la vía materna será el medio de transmisión del legado cultural, heredado y conservado como testimonio del sustrato identitario. El rol de la mujer es definitorio en este sentido, por ella se realizan los contactos con el universo imaginario familiar, la lengua materna es el núcleo más sólido de identidad trascendente, tanto inmigrante como la perteneciente a una cultura original. Ese universo lingüístico actualiza, en el texto, una forma de nombrar el mundo, con vocablos de léxico mapuche. El relato se abre y cierra con la muerte del adelantado Enrique Enríquez de Guzmán, reproduce la concepción del tiempo circular, como reflejo de la idea cíclica del devenir, propia del pensamiento mítico original de las culturas precolombinas.

Doble relación de sometimiento, al orden familiar: al padre o al esposo, a tíos o hermanos en los casos de orfandad o soltería, y al orden social en relación de vasallaje, que le vino al hombre español y funcionario en la etiqueta manipuladora de ultramar: el derecho feudal de la monarquía absolutista, en la persona del Rey y el donatario intermediariamente beneficiado por el sistema de concesiones de propiedad. Vasallaje en segunda instancia que justificaba la subordinación femenina en toda relación genérica.

IDENTIDAD Y ALTERIDAD DEL SIGNIFICANTE MUJER

La documentación de los cronistas ubica a todo el siglo xvir dentro de la problemática del estado de herejía, la extirpación de idolatrías, y en lo que fuera la represión despiadada contra todo vestigio de conservación de costumbres, manifestación de una tradición de pensamiento, lenguaje e identidad autóctona en suma, situación encubierta de lo se puede llamar violación cultural. Esta conflictiva situación condiciona a la hechicera y licenciosa mestiza Catalina de los Ríos, que estará sujeta por el sacramento del matrimonio como lo manda la Santa Iglesia, a fin de poder arrancarla de ese estado de herejía. Participando de dos mundos antagónicos, por la rama de sangre europea: alemana y española, revuelta en mescolanza con sangre mapuche, promete cumplir con sus deberes cristianos, en lo que respecta a donaciones de fondos destinados al rescate de cautivas, limosnas a conventos, 
hospitales para pobres, misas por las almas, que superpone a conjuros, hechizos, los sueños y presagios.

Si la sed de ser es acallada por la violencia del silencio, a fines del mismo siglo, en Méjico, Virreinato de Nueva España, la sed de saber de Sor Juana Inés de la Cruz también sufrirá igual condena pública por la defensa personal de la libertad de pensamiento. El padre Diego Calleja, entre sus biógrafos recompone su imagen y verdadera identidad:

La extraordinaria escritora mejicana fue hija natural de una india analfabeta y de un español vasco y pasaba por criolla siendo mestiza. (Calleja 535)

La mejor semblanza es la que dan sus escritos en prosa, tanto Primero Sueño, como la Carta a Sor Filotea de la Cruz, que documentan los conflictos de su vida causados por la defensa de la libertad de pensamiento.

"El conquistador tomó a la mujer y a la tierra y las hizo suyas en un plan de sexualidad y pertenencia jurídica” (Tamayo Vargas 447). Así inscribe Augusto Tamayo Vargas la concepción del latinoamericano enfrentado al mestizaje, que Ángel Rama expusiera orgánicamente como diálogo violento entre dos culturas: fricción cultural como acentuación del mestizaje. En respuesta a esta situación de conquista y colonización aparece la rebeldía femenina:

La mujer se escapa de la casa y se hace la tapada, y la chola domina al hombre. La Perricholi domina al septuagenario Virrey Amat. Rescatamos la insurgencia Revolucionaria de Micaela Bastidas, junto a su esposo José Gabriel Condorcarqui -Tupác Amarú, quienes protagonizaron la primera gran Rebelión con base económico social que se dio en América. (Tamayo Vargas 445)

La sumisa inferioridad femenina con la que tradicionalmente se nos circunscribía a una virtualmente cómoda posición social, será revertida en la historia tanto por el protagonismo de algunas mujeres en hechos relevantes como por el de otras personalidades femeninas desbordadas en su existencia literaria y encarnadas en leyendas o fábulas populares: personajes históricos que la leyenda popular transformaría en mitos.

Cotejando lo que Augusto Tamayo Vargas trajera a colación -en lo referente al complejo de la Malinche y lo que significa chingarse para el mejicano explicado también por Octavio Paz en El laberinto de la soledad- la deshonra que implicara ser hijo de una mujer que voluntariamente se entrega al conquistador -que el mito de la Quintrala revierte como la otra cara de la misma moneda o el derecho y envés de la misma tela en el dicho popular- brinda una imagen de mujer mestiza, escindida entre los pormenores de la vida virreinal a la que se la quiere sujetar: llámese ésta, obediencia paterna o complacencia sexual con los funcionarios.

Así, orden social y coyuntura existencial configuran el desdoblamiento de su yo profundo, que vive en sí la contingencia de una raza con la que se identifica por vía materna, sangre heredada de mujer revivida como leit-motiv del texto, y que es, en última instancia, la que define y defiende a ultranza su condición mujer: 


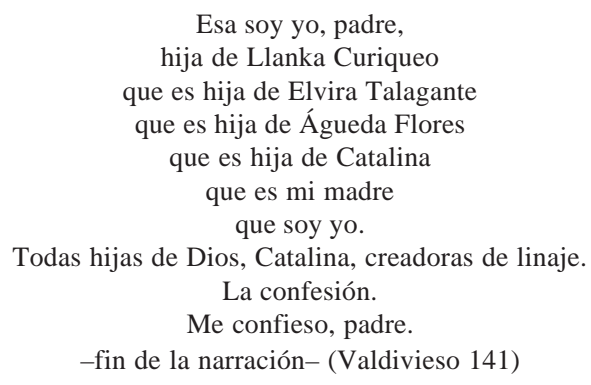

A nivel del enunciado este segmento de la narración, denota la superposición, el sincretismo de la doble vía identitaria: el linaje heredado y la aceptación de considerarse hijas de Dios, al someterse a la confesión. Esta imagen, barroca en sí misma, asume, capta y refleja a nivel textual la problemática profunda del yo colonizado, de un yo colectivo que concentra en sí mismo la dualidad impuesta. El locus identitario resuelve la ambigüedad y da una versión oficial, las reglas de obediencia se aceptan, se cumplen, y se declaran en voz alta.

La retórica colonial construyó una red de imágenes, de fórmulas al servicio de la estructura triunfalista que tenía como fin exaltar el sometimiento del espacio pagano a un orden real, del cual la imagen barroca, pictórica o verbal, adoptaba una función unificadora en un mundo que se develaba en la complejidad de la mezcla mestiza, ${ }^{6}$ donde el fin religioso sustituye al designio político, eslabones de una red imaginaria que riega intercambios que sueldan la sociedad novohispana.

En una nota final de la novela, Mercedes Valdivieso se ubica en "el atrevimiento de meterse con Catalina de los Ríos y Lisperguer, Quintrala de la leyenda, única mujer que menta y menta para mal la historia del siglo xvII" (142).

En esta novela reconstruye el personaje rescatándolo del mito, trabajando fuentes documentales de la Biblioteca del Congreso de Washington D. C. y de Austin, Texas. Trabajo en el cual participaron amigos y estudiantes de la Universidad de Rice, en Houston, a quienes ella reconoce expresamente la pertenencia del texto, y con los cuales compartió este acto escritural, incorporando sus experiencias como docente de literatura y cultura hispanoamericana, y la labor historiográfica en fuentes originales de la crónica histórica.

En este sentido, se infiere que toda construcción es artificio o que toda historia actualizada es ficción. Resemantizar la historia y poder saber llenar los espacios en blanco del significante mujer forma parte de un proyecto propio de la ficción desde el verosímil del presente. La historia, revive ágil en el estilo que con maestría Valdivieso ha logrado

\footnotetext{
6 “La imagen barroca no sólo es una efigie milagrosa, o un objeto de culto. También designa una gama totalmente distinta de representaciones minoritarias que mezclan lo político, lo alegórico y lo mitológico. / ¿Hasta qué punto eran viables, hasta qué límite se podía obrar desde dos modos de enfocar la realidad y la persona que parecen irreconciliables y mantener un equilibrio entre dos lenguajes para obtener una síntesis original?” en La guerra de las imágenes, de Serge Gruzinski.
} 
imprimir con un alto contenido expresivo, reproduciendo el tipo de construcción sintáctica del habla de la época, manteniéndose fiel en los giros y las expresiones, pero alivianándola con un coloquialismo sostenido.

La ruptura que operan falsos estereotipos importa como desafío a la ficcionalidad del sistema social que supone una igualdad de derecho, no de hecho, así como repensar conservar los vestigios culturales autóctonos. Nos dice Néstor García Canclini en Imaginarios Urbanos, que la función de lo actual es un momento de transición, transición que Paul Ricoeur (12) define como un proceso dinámico, en el cual la construcción y renovación de lo imaginario tiene una tendencia a reconceptualizar lo instituido, a reelaborar nuestro patrimonio, a re-imaginar los hechos de nuestro pasado en indisoluble relación con nuestro presente, y donde la ficción se inmiscuye con ellos para legitimar raíces comunes y fortalecer la memoria colectiva; que nos es simbólicamente dada desde un comienzo anterior a nosotros. En la transmisión de lo imaginario, lo prefigurado, lo culturalmente heredado, entra en relación dialéctica con lo transfigurado. Así, la transfiguración es un proceso dinámico de innovación y renovación imaginaria que nos suministra un sentido más amplio de la tradición. Lo que importa es cómo trabaja el escritor la ficcionalización de la historia.

DOY POR VIVIDO TODO LO SOÑADO DE ISIDORA AgUIRRE

Isidora Aguirre, dramaturga chilena de larga trayectoria, nació alrededor de 1920. Su producción autoral ha estado mayormente dirigida al teatro con obras y comedias musicales de gran difusión, como por ejemplo La pérgola de las flores. Tardíamente se acerca al tema popular por medio de la narrativa. Doy por vivido todo lo soñado fue publicado en 1989 por Plaza y Janés, editores españoles; a pesar de ser esta una edición extranjera, no es una producción de exilio. En su temática recompone vigorosamente los recuerdos de la historia familiar de Laura Cupper, alternando las hazañas de sus antepasados con los amores felices -y no tanto- de las mujeres de su familia. A través de recortes de historia chilena desde la Independencia, el relato familiar aparece bien sazonado con datos acerca de la emancipación de la mujer-lograda a través del cultivo del arte y la hospitalidad hogareña, mientras el buen pasar así lo permitiera, antes de que la calamitosa decadencia material sentara sus reales en la mansión de la calle de las Monjas Rosas, un caserón semi derruido próximo al centro santiaguino.

El rasgo común que acerca esta obra a Maldita yo entre todas las mujeres es el espacio extra-territorial que le permite a una voz femenina, la de todas las mujeres:

yo, mi hermana, mi mamá Laura, mi abuela Teresa, mi bisabuela Isolda, contar nuestra historia. (Aguirre 7)

EL PASADO COMO HUIDA DEL PRESENTE

La creación literaria de ese espacio propio, donde re-describir la vida es al igual que para Catalina, ("Y en mí todas las mujeres de mi sangre”), una utopía que le permite evitar el presente: 
¡Date prisa en rescatar lo que puedas! Están fusilando afuera, no sea que nos fusilen también la magia: podríamos acostumbrarnos a vivir sin la poesía. (8)

La imaginación utópica es la que nos permite realizar en la narración una disyunción entre el aquí y el ahora real: el posgolpe chileno y las calles de Santiago. El ningún lugar tiene un sentido atemporal: rescatar la memoria de los recuerdos que aún nos quedan y en un escamoteo distanciarnos de las difíciles condiciones que impone el estado de sitio: enunciado desde el comienzo de la novela, en su primer capítulo

\section{ENTREPARÉNTESIS}

(Abre paréntesis): Conviene adentrarse con cautela en los laberintos de la memoria, tanteando huellas y buscando la puerta precisa. De otros modos corres el riesgo de convertirte en asesina de recuerdos.

Es mi hermana Palmira la que habla. O quizás sea la última descendiente de una casta de rumiantes -casta ya perdida-, de los que rechazan el diario acontecer para refugiarse en las reminiscencias que no importa si se mezcla lo vivido y lo soñado, pero que cuenten. ¡Cuenten lo más posible! -dice una voz lejana. (7)

Con estas palabras que abren el relato, finaliza aparentemente el primer capítulo, el que es retomado al final de la narración. Los interlocutores de este diálogo ficcional entre Laura y Palmira, dan el mensaje clave de esta conversación que alegoriza un presente y cierra una obra que figurativamente nos habla del pasado para no hablar del presente.

EL REALISMO DE LA DECREPITUD, EL CASO CHILENO

Desde la tradición literaria este discurso extraño es categorizado dentro de las tendencias regresivas, las nostalgias por el pasado o por un paraíso perdido, como fatalidad que se impone a la cultura latinoamericana a causa de sus orígenes coloniales. Ángel Rama en la agudeza de su análisis (164-68) encuentra que esta tercera corriente sería paralela al realismo crítico urbano y a la literatura fantástica, tendencias con resoluciones bien diferentes aunque tengan el referente urbano como denominador común.

Galería de recuerdos, atmósfera de irrealidad, realidad de decadencia material, promiscuidad de objetos con la imborrable presencia de los espíritus de sus dueños:

Se acumulan las decrepitudes -se quejaba (Laura) hablando con las paredes. (Aguirre 7)

Este realismo de la decrepitud o discurso extraño, tiene su mejor exponente en José Donoso. En La Coronación están ya perfilados los temas de la decadencia y la desintegración de la clase alta. Tópicos que se revelaran en plenitud con El obsceno pájaro de la noche, temas que la generación de los años cincuenta abordara desde el realismo crítico urbano, que la característica estilística de Ángel Rama (174) describe con maestría: una aparente simplicidad de estructuras lingüísticas, de motivos y temas que "con una tenaz grisura" delatan las tradiciones regionales de una austera clase superior que desciende de hacendados. Esta caracterización expuesta con escasas variaciones por los países del área andina configura una crítica, sino social, moral de las clases altas. 
La originalidad en el tratamiento del tema de la descomposición de clase es proyectada en esta obra como un proceso que revierte la evolución y que en una suerte de cuenta regresiva clausura sus zonas de comunicación social, hasta retorcerse en un delirante encierro verbal.

Clausura social fatalmente decretada por la pérdida de protagonismo de los referentes pertenecientes a estructuras rígidas y anquilosadas de un orden social caduco. Pérdida de esplendor material y decadencia social, que se autonomizan discursivamente en una superación estética de la génesis temática original:

Doy por vivido todo lo soñado: ¡Demos por ganado todo lo perdido y por recibido todo lo esperado! (201)

Temática que textualiza una dimensión significativa más vasta: comienza con el relato de una vida familiar activa, que alimentara sus días con la evocación de glorias patricias. Infancia feliz, irreal mundo aparte, por donde se filtraban los comentarios polémicos de Fermín Errauriz, el marido ingeniero, de origen español, cuyos padres llegaran al país en alpargatas, "con una mano atrás y otra adelante”.

Esposo trabajador y complaciente, quien financiaba una vida de comodidades y excentricidades. Buen pasar que dependiera del precio del estaño, opulencia sobre la cual Laura y Fermín coincidían en que 'no iba a durar' y sobre la cual sobrevendría conocer la novedad de la pobreza. Este discurso extraño que comienza el día en que Laura cumple setenta y cinco años y que en una incontinencia de recuerdos, veinticuatro horas le alcanzan para desandar el camino. Entonces como succionada por el tiempo, lo extraordinario desborda lo cotidiano, las reencarnaciones son cosa de cada momento.

Pantano de recuerdos que le devolviera el pasado, una Laura desdoblada que conversa con sus muertos. Es una mirada oblicua sobre un poco común espejismo que nos atrevemos a imaginar como un loco ensamble dialógico de fechas y lugares distantes, donde Laura cae, de a ratos, en trance y retrocede cruzando las nieblas del pasado. Pasado desde donde las termitas vinieran a traerle el mensaje de sus antepasados, residuos que desbordan místicamente las paredes de los cuartos, buscando revivir amores frenéticos o platónicos, tristes y nostálgicos como el de su hermana Palmira hacia Lorenzo, dando el agradecimiento póstumo a su Fermín que supo resistirla en sus veleidades artísticas y espiritistas.

Saltando de la isla de Chiloé, con su bisabuelo el Coronel Cupper, a Quiquilco, hasta la hacienda al sur, en los faldeos cordilleranos, los paseos al fundo de Mallermo de las tías Cupper o el viaje al balneario del Zapallar: pero con un ojo puesto en París, con esa nostalgia europea propia de los biennacidos del nuevo continente.

Pasado revivido en conversaciones de sobremesa, en diálogos de amantes, en tertulias con huéspedes como los de la etapa ruso blanca, ecos lejanos de la revolución bolchevique, o los de la etapa española, por los franquistas que despistados huyeran, creyéndose derrotados.

Del piano con sus polkas caemos al suelo mecidos por balalaikas, o enganchados en los charlestons y fox-trots de la vitrola ortofónica bailamos sin parar. Una vida de sabores endulzan "esta vida sin pecados": los dátiles africanos envueltos en fino papel de seda, 
sagú con merengue, bavarois de Lúcuma, jaleas temblorosas, termitas, mudanzas, polvillo de greda, heliotropos en desbordante evolución. Son los toques que le dan el matiz barroco a una historia escarbada entre diarios de campaña, diarios íntimos, epistolarios amorosos o en contactos de ultratumba.

Todo dicho artísticamente, resuelto entre lágrimas, risas - porque hay mucho humor, suspiros y un dejo sarcástico. Sarcasmo donde se mezclan la burla y la auto-conmiseración. Popurrí de milagrería y necrofilia: desopilante panegírico familiar. Prosa cuyo montaje responde a una bien aplicada técnica de bricolaje, de hiperbólico coloquialismo que disimula un monólogo, paradojalmente callado a voces, porque los locutores sólo hablan consigo mismo y en la supuesta soledad de su memoria. Efecto estético que produce una fascinación imaginaria, un encantamiento transitorio, abruptamente suspendido cuando los lectores participan cómplices de un pacto de silencio: observan con ilusión de pasado un tiempo estrictamente presente. En las últimas páginas de la novela, del epistolario amoroso entre Palmira, hermana de Laura, a su amado Lorenzo:

Sí, tienes razón. No debo seguir hurgando en tus cartas. Pero, ¡qué quieres tengo cada cierto tiempo para soportar las muertes históricas y los descalabros. La negrura de los días de hoy. La impotencia de no saber cómo librarnos de los fusiles. Tú que huiste a tiempo, préstame tus ojos limpios. Y basta. De veras no pensaba mencionarte nada de esto, pero te confieso finalmente que TÚ eres mis tiempos míticos (Y será lo último que te diga, porque ya está gritándome mi hermana "Quedamos en que NO HABLARÍAMOS DEL PRESENTE, Palmira!”). (226)

Consideramos pertinente establecer aquí la particular relación entre tema y estrategia textual que patentiza la literatura del Posgolpe en Chile. Siguiendo a Raúl Zurita, "las estrategias textuales que tienen como fin implícito el burlar y sortear esos mecanismos represores y que allí el tema escogido no es más que una pantomima de esa relación”. (Zurita 58).

El trabajo textual de Isidora Aguirre exhibe el modo en que la imaginación, como ficción, neutraliza esa aparente normalidad. En la literatura del Posgolpe se quiebra el régimen conversacional; allí ubicamos lo no-dicho como eje ordenador del lenguaje. A partir de 1973 se produce el recluimiento y privatización de la lengua en la esfera individual. Y esta novela, como la de Mercedes Valdivieso, muestra, merced a la trascendencia literaria, la privacidad discursiva de lo íntimo y lo cotidiano, donde la individualidad se extiende como hecho público. Hay una tensión ideológica que informa al lenguaje y, en este caso, proyecta argumentativamente, el afuera en el adentro:

Suficiente para recordar, afuera los fusiles, dentro nuestro la magia y la poesía. (7)

El efecto generador de auto-comprensión es convincente. Ante una internalización consciente o no de la autocensura, hay contenidos que no se evidencian ya fuere por elementos referenciales como por la re-activación de la conciencia del hablante. Es, entonces, a partir de la constatación del desmentido como categoría de preservación del lenguaje públicamente censurado, controlado, que se gesta un mecanismo de 
sobreentendidos, donde la comunicación se re-codifica. Re-codificación que la literatura desvía en mayor o menor grado del uso normal del lenguaje cuyos términos han dejado de ser unívocos.

SENTIDO DE LA TRADICIÓN

Salvando las distancias temporales de ambas ficciones narrativas, hay un énfasis puesto en la re-unifación parental que revela el espíritu de clan, de estirpe, en la sociedad chilena, presente en los ejes temáticos de ambas obras. Rasgo que podría ser percibido como una categoría antropológica dado que apunta a identificar las estrías más duraderas de nuestra condición temporal, aquéllas menos vulnerables a las vicisitudes de cualquier orden.

Por otra parte y, como otro lazo que desborda el vínculo del sujeto con su entorno afectivo y de sangre del núcleo familiar, ambas obras formulan la aceptación social desde diferentes locus. Temática ésta que, en Doy por vivido todo lo soñado aparece como valoración positiva del mundo fabulado, y en su elección de auto-confinamiento discursivo, explicita la clausura de un apogeo social en ciernes. En la justificación del virtual cerrar de puertas para contar, mantiene una supuesta intimidad narrativa, en respuesta a una oblicua visión del mundo, y a una perspectiva de vida restringidamente individualista.

Las coordenadas entre lo histórico y la ficción quedan tendidas, conflictivamente, en el diálogo violento sostenido entre la cultura mapuche heredada por el linaje femenino del cacicazgo de Talagante y los interesados fines de la cultura del conquistador. Partes de un todo, de un estéril proyecto de convivencia social estratificada, cuya finalidad intrínseca (en dos variantes históricas) estaba en la intacta preservación de la jerarquía dentro del orden social; modos dialécticos de definir la identidad y asumir simbólicamente la alteridad como un constructo cultural: soy en tanto el otro me reconoce y legitima dentro de un orden dado.

\section{BiBLIOGRAFÍA}

Aguirre, Isidora. Doy por vivido todo lo soñado. Barcelona: Plaza \& Janés, 1987.

América latina en su literatura, publicación de UNESCO. México: Siglo xxi Editores, 1ª Ed., 1972, 9a. Ed. 1989.

Antropológica 2/2 (Revista del Departamento de Ciencias Sociales de la Pontificia Universidad del Perú, 1984).

Bertrand Roussel, Pierrele. “A propósito de la mitología shipibo”. Revista Antropología II/2 (Pontificia Universidad Católica del Perú, 1984).

Calleja, Diego. Hazer fineza el desaire. S.E.: S.N., 1700-1799?

Donoso, José. La Coronación. Santiago de Chile: Alfaguara, 1995.

El obsceno pájaro de la noche. Santiago de Chile: Alfaguara, 1970.

Duvoils, Pierre, Cultura Andina y represión: procesos y visitas de idolatrías y hechicerías, Cajatambo, Siglo XVII. Cusco: Centro Bartolomé de las Casa, Biblioteca de Archivos de Historia Andina 5, 1986. 
García Canclini, Néstor. Imaginarios Urbanos. Buenos Aires: Editorial Universitaria de Buenos Aires, 1997.

Geertz, Clifford. "La interpretación de las culturas”. La ideología como sistema cultural. México: Gedisa, 1987.

Gruzinski, Serge. La guerra de las imágenes: de Cristóbal Colón a “Blade Runner” (1492-2019). México: Fondo de Cultura Económica, 1994.

Jofré, Manuel Alcides. "La novela en Chile: 1973-1983”. Fascismo y experiencia literaria: reflexiones para una recanonización.Minneapolis: Institute for the Study of Ideologies and Literature, 1986.

Literatura chilena en el exilio. Chile: CENECA (Centro de Investigación y Expresión Cultural y Artística), 1986.

Paz, Octavio. El laberinto de la soledad [1950] México: Fondo de Cultura Económica, 1984.

Rama, Ángel. La novela en América Latina, (Panorama 1920-1980). México: Ed. Fundación Ángel Rama-Universidad Veracruzana, 1986.

Ramos, Gabriela y Henrique Urbano (Comps.). Catolicismo y extirpación de idolatrías $S$. XVI-XVII, Charcas, México, Chile, Perú. Cuadernos para la Historia de la Evangelización en América Latina. Cusco: Centro de Estudios Regionales Andinos, 1993.

Ricoeur, Paul. Ideología y Utopía [1988]. George H. Tyler, comp. Barcelona: Gedisa, 1994.

Rodríguez, Rosa María. "La seducción de la diferencia”. Biblioteca A conciencia 2. Barcelona: Editorial Anthropos, 1994. 69-71.

Rodríguez, Silvia C., La Alteridad, poemario en Trampas y fuego, con otros, inédito.

Tamayo Vargas, Augusto. La angustiada vida del ingeniero Aet. Río Piedras, PR: Universidad de Puerto Rico, 1972.

Tomoeda, Hiroyasu y Luis Millones (Eds.). 500 años de Mestizaje en los Andes. Lima: Seminario Interdisciplinario de Estudios Andinos, Biblioteca Peruana de Psicoanálisis, 1992.

Urbano, Henrique. Mito y simbolismo en los Andes: la figura y la palabra. Cusco: Centro de Estudios Regionales Andinos Bartolomé de las Casas, 1993.

Valdivieso, Mercedes. Maldita yo entre todas las mujeres. Santiago de Chile: Planeta, 1991.

Zurita, Raúl, Literatura, lenguaje y sociedad (1973-1983). 4ta. edición. Santiago de Chile: Centro de Indagación y Expresión Cultural y Artística, 1988. 